\title{
SOCIOECONOMIC CHANGES AND WOMEN EMPOWERMENT THROUGH KUDUMBASHREE MISSION- STUDY OF MUKKAM MUNICIPALITY
}

Annie John ${ }^{1}$

${ }^{1}$ Associate Professor, Department of Community Medicine, KMCT Medical College, Manassery, Mukkam.

ABSTRACT

\section{BACKGROUND}

Development of a nation cannot be separated from or viewed in isolation from the development of women. Kudumbashree is a female oriented community-based poverty reduction project by the Govt. of Kerala which was launched on May 17, 1998, in which many developmental experiments are being tested, refined and implemented. The mission aims at the empowerment of women by providing self-employment opportunities through formation of self-help groups by which they succeed in making a significant dent on poverty.

\section{MATERIALS AND METHODS}

Study Design- Descriptive study.

Study Settings- Mukkam municipality.

Study Population - Kudumbashree members in Mukkam taluk.

\section{RESULTS}

Kudumbashree has improved the social status of women. Through Kudumbashree they have improved their confidence in banking and money transactions. They could improve their communication skills and their skills in planning and implementing projects. The participation of women in social programmes, public meetings has improved to a great extent. Kudumbashree has enhanced entrepreneurship and leadership and the capacity of women to work and earn together.

\section{CONCLUSION}

The study has provided an insight on women's empowerment acquired by Kudumbashree members after joining Kudumbashree. Economic development is the basis for other development. Economic development of women leads to a better living status.

\section{KEYWORDS}

Kudumbashree, Socioeconomic Changes, Women Empowerment.

HOW TO CITE THIS ARTICLE: John A. Socioeconomic changes and women empowerment through Kudumbashree mission- Study of Mukkam municipality. J. Evolution Med. Dent. Sci. 2017;6(55):4120-4123, DOI: 10.14260/Jemds/2017/892

\section{BACKGROUND}

Women are the basic unit in the family who are shouldering almost all the responsibilities of the family. But they have to suffer inequalities and harassment in all the phases of their life from womb to tomb. ${ }^{1}$ Poverty eradication and women empowerment are the widely discussed topics all over the world. ${ }^{2}$ Development of a nation cannot be separated from or viewed in isolation from the development of women who constitute half of world's population and who can certainly play a crucial role in influencing the course of human history as well as shaping the destiny of mankind. It has been acknowledged in several studies that the social and economic empowerment of women has a positive impact on poverty eradication and economic development of the country. ${ }^{3}$

It is following this awakening that the Govt. of Kerala has taken up such a supporting project as Kudumbashree mission for women welfare and empowerment in the society.

Financial or Other, Competing Interest: None.

Submission 05-06-2017, Peer Review 29-06-2017,

Acceptance 05-07-2017, Published 10-07-2017.

Corresponding Author:

Dr. Annie John

Associate Professor,

Department of Community Medicine,

KMCT Medical College,

Manassery P.O., Mukkam.

E-mail: dranniejohnputhuchira@gmail.com

DOI: $10.14260 /$ jemds $/ 2017 / 892$
Kudumbashree is a female oriented community-based poverty reduction project by the Govt. of Kerala which was launched on May 17, 1998, in which many developmental experiments are being tested, refined and implemented. The mission aims at the empowerment of women by providing self-employment opportunities through formation of selfhelp groups and encouraging their entrepreneurial and other wide range of activities, by which they succeed in making a significant dent on poverty in the state. It also ensures that women should no longer remain as passive recipients of public assistance, but act as active leaders in development. Gurumoorthy ${ }^{4}$ (2000) reveals that empowering women contributes to social development.

It is important to know about the current status of the members of Kudumbashree to know about the improvements needed in the policies of the governments and also such studies have not been done in our locality so far. So, it was planned to conduct a study to assess the socioeconomic changes and empowerment of women after their participation in Kudumbashree and also how Kudumbashree participation enabled in changing the life of women of lower socioeconomic status.

\section{Aims and Objectives}

- To assess social changes through Kudumbashree.

- To assess economic changes through Kudumbashree. 
- To measure the role of Kudumbashree in women empowerment.

\section{MATERIALS AND METHODS}

Study Design- Descriptive study.

Study Settings- Mukkam municipality.

Study Population- Kudumbashree members living in Mukkam Municipality.

Study Period-14 November 2016 to 26 November 2016.

\section{Sampling}

From the total 51 different Kudumbashree units in Mukkam municipality, 100 Kudumbashree members were selected by simple random method by lot technique.

\section{Inclusion}

Members who have completed at least 3 years in Kudumbashree and are still present.

\section{Exclusion}

Members who left Kudumbashree.

Tools Used-Pretested semi-structured questionnaires.

\section{Methodology \\ Data Collection}

A batch of 23 MBBS students divided into six groups were assigned for data collection. Data was obtained by interviewing the Kudumbashree members using pretested semi-structured questionnaires prepared in local language.

\section{Questionnaires}

Three sets of questionnaires were used to collect the information. First set comprised of questions regarding social changes of members after joining Kudumbashree. Second set comprised of thirteen questions on economic changes and third set comprised of questions on women empowerment of members after joining Kudumbashree. These questionnaires were designed to obtain information about how Kudumbashree has helped in changing the life of its members.

\section{Analysis}

All the information collected from the members through the interviews were collated. Data entry and analysis was done using Microsoft Excel (Version: 2007).

\section{RESULTS}

\begin{tabular}{|c|c|}
\hline & Frequency (\%) \\
\hline Age Category & $2(2)$ \\
$\leq 24$ years & $11(11)$ \\
$25-34$ years & $39(39)$ \\
35-44 years & $45(45)$ \\
45-64 years & $3(3)$ \\
$\geq 65$ & \\
\hline Economic Level & $46(46)$ \\
Above Poverty Line & $54(54)$ \\
Below Poverty Line & $1(1)$ \\
\hline Education & $75(75)$ \\
Illiterate & $14(14)$ \\
Middle/High school & $10(10)$ \\
Higher secondary & \\
College degree &
\end{tabular}

\begin{tabular}{|c|c|}
\hline Marital status & $82(82)$ \\
Married & $5(5)$ \\
Unmarried & $13(13)$ \\
Divorced /separated/Widow & Table 1. Frequency Distribution of Baseline Data \\
\hline \multicolumn{2}{|c|}{}
\end{tabular}

Out of the total 100 women studied, $45 \%$ were in the age group $45-64$ years, 2\% were below 24 years and 3 were above 65 years. More than half (54\%) of the study subjects belonged to Below Poverty Line category. Majority (75\%) of the study subjects had an education level of either middle or high school level, one was illiterate and ten had a college degree. Most (82\%) of them were married.

\section{Social Changes through Kudumbashree}

\begin{tabular}{|c|c|c|}
\hline & Improved & Not improved \\
\hline $\begin{array}{c}\text { Participation in social } \\
\text { programmes after joining } \\
\text { Kudumbashree }\end{array}$ & $89 \%$ & $11 \%$ \\
\hline $\begin{array}{c}\text { Participation in public meetings } \\
\text { after joining Kudumbashree }\end{array}$ & $90 \%$ & $10 \%$ \\
\hline $\begin{array}{c}\text { Improvement in } \\
\text { confidence in banking and } \\
\text { money transactions }\end{array}$ & $95 \%$ & $5 \%$ \\
\hline $\begin{array}{c}\text { Ability to coordinate } \\
\text { meetings and express opinions }\end{array}$ & $90 \%$ & $10 \%$ \\
\hline $\begin{array}{c}\text { Improvement in } \\
\text { communication skills }\end{array}$ & $95 \%$ & $5 \%$ \\
\hline $\begin{array}{c}\text { Table 2. Assessment of Social } \\
\text { Changes through Kudumbashree }\end{array}$ \\
\hline
\end{tabular}

Kudumbashree has enabled social changes in the study subjects as shown in Table 2. Majority (89\%) agreed that their participation in social programmes has improved after joining Kudumbashree. About $90 \%$ of study subjects responded that their participation in public meetings and ability to coordinate meetings and express opinions improved after joining Kudumbashree. Improvement in confidence in banking, money transactions and also communication skills was reported by $95 \%$ of the study subjects. About $20 \%$ of the study subjects were affiliated to one or other political party (Not shown in the table).

\section{Economic Changes Due To Kudumbashree}

\begin{tabular}{|c|c|c|}
\hline \multirow{2}{*}{} & $\begin{array}{c}\text { Before joining } \\
\text { Kudumbashree }\end{array}$ & $\begin{array}{c}\text { After joining } \\
\text { Kudumbashree }\end{array}$ \\
\cline { 2 - 3 } & Frequency (\%) & Frequency (\%) \\
\hline Unemployed & 74 (74) & 51 (51) \\
\hline \multicolumn{2}{|c|}{$\begin{array}{c}\text { Table 3. Frequency of Unemployment } \\
\text { before and after Joining Kudumbashree }\end{array}$} \\
\hline
\end{tabular}

The prevalence of unemployed among the study subjects decreased by 23 points after joining Kudumbashree.

\begin{tabular}{|c|c|c|}
\hline & Improved & $\begin{array}{c}\text { Not } \\
\text { improved/Increased }\end{array}$ \\
\hline Family income & $48 \%$ & $52 \%$ \\
\hline House facilities & $66 \%$ & $34 \%$ \\
\hline $\begin{array}{c}\text { Number of property } \\
\text { owned }\end{array}$ & $28 \%$ & $72 \%$ \\
\hline \multicolumn{2}{|c|}{ Table 4. Economic Changes due to Kudumbashree } \\
\hline
\end{tabular}


More than half (52\%) reported that their family income has not improved after joining Kudumbashree. Housing facilities improved after joining Kudumbashree in the cases of $66 \%$ women, but $72 \%$ responded that there was no increase in the number of properties they owned after joining Kudumbashree. When need arose, 59\% of the women received financial support from Kudumbashree.

\section{Women empowerment Due to Kudumbashree}

\begin{tabular}{|c|c|c|}
\hline $\begin{array}{c}\text { Decision making in } \\
\text { household affairs }\end{array}$ & Improved & $\begin{array}{c}\text { Not } \\
\text { Improved }\end{array}$ \\
\hline $\begin{array}{c}\text { Decision making in } \\
\text { property buying matters }\end{array}$ & $67 \%$ & $9 \%$ \\
\hline $\begin{array}{c}\text { Decision making about } \\
\text { education of children }\end{array}$ & $90 \%$ & $10 \%$ \\
\hline $\begin{array}{c}\text { Expressing views in the presence } \\
\text { of husband and family members }\end{array}$ & $83 \%$ & $17 \%$ \\
\hline $\begin{array}{c}\text { Visiting different places (market, } \\
\text { hospital, temple, family relatives) } \\
\text { without permission } \\
\text { of family members. }\end{array}$ & $76 \%$ & $24 \%$ \\
\hline $\begin{array}{c}\text { Attitude of family members } \\
\text { towards you on travelling alone }\end{array}$ & $90 \%$ & $10 \%$ \\
\hline $\begin{array}{c}\text { Confidence level in negotiating and } \\
\text { bargaining in financial matters }\end{array}$ & $86 \%$ & $14 \%$ \\
\hline $\begin{array}{c}\text { Freedom to spend } \\
\text { money for own needs }\end{array}$ & $82 \%$ & $18 \%$ \\
\hline $\begin{array}{c}\text { Planning and } \\
\text { implementing projects }\end{array}$ & $82 \%$ & $18 \%$ \\
\hline Quality of life improvement & $85 \%$ & $15 \%$ \\
\hline Table 5. Assessment of Women Empowerment \\
\hline \multicolumn{2}{|c|}{}
\end{tabular}

Ninety one percent of the study subjects admitted that the decision making power in household affairs (daily affairs) greatly improved due to Kudumbashree. About $67 \%$ of the respondents said that there has been an improvement in their decision making power in property buying in the family. About $90 \%$ have said that their decision making power in education of their children improved after joining Kudumbashree. Other indicators of women empowerment such as expressing their views, the ability to visit different places (market, hospital, temple, family relatives) without permission of family members, the attitude of their family members towards their travelling alone and freedom to spend money for own needs was reported to have improved in $83 \%, 76 \%, 90 \%$ and $82 \%$ of study subjects respectively after joining Kudumbashree. Around $86 \%$ has said that their confidence to negotiate and bargain in financial matters improved after joining Kudumbashree. Ability to plan and implement projects such as health education classes, farming, and seeds distribution has improved in $82 \%$ after joining Kudumbashree. Around $85 \%$ of study subjects agreed that their quality of life has improved after joining Kudumbashree. None of the study subjects experienced domestic violence from their family members/husband (Not shown in the table).

\section{DISCUSSION}

There were many attempts to analyse the effectiveness and impact of Kudumbashree on poverty in view of changing socioeconomic scenario and women empowerment in the state. Kenneth Kalyani, ${ }^{1}$ Seena PC (2012) reveal that economic development is the base of other development. Economic development of women leads to better living standards. In our study, after joining Kudumbashree the socioeconomic status of the families improved.

Puhazhendhi and Sathyasai (2001) ${ }^{5}$ in their study attempted to evaluate the performance of Self-help Groups (SHG) with special reference to social and economic empowerment. The findings of the study reveal that SHGs could positively contribute to the economic and social empowerment of rural poor. In our study also, Kudumbashree has improved the social and economic empowerment of women. Jaya S Anand (2002) ${ }^{6}$ has stated in her discussion paper on Self-help groups in empowering women, that the supporting structures in delivering credit are critical to make the impact of group activity strong and sustainable.

Sri V. P Raghavan $(2009)^{7}$ in his article stated that the poor women of the state have become participants of various antipoverty programmes. In our study also, the members actively participated in several anti-poverty programmes. Minimo MC and Mahesh KG (2012) ${ }^{8}$ in their study identified that intellectual empowerment is more important. In our study, $59 \%$ of the members improved their confidence in banking and money transactions.

According to the study conducted by Beena C. A. and Sari T. $\mathrm{C}^{9}$, level of empowerment in financial management skills was at moderate level. Freedom to spend money for their own needs represented very low level of improvement. In our study, there is $82 \%$ improvement.

In this study, only $20 \%$ of study subjects are affiliated with one or other political party, while in Dr. K. Venugopalan's ${ }^{10}$ study $31 \%$ members improved, $15 \%$ fairly improved and 53\% did not improve their involvement in politics. This is because the respondents of his study were already affiliated to political parties but ours were interested only after joining Kudumbashree.

In this study, there is $76 \%$ improvement in visiting different places (market, hospital) without the permission of family members, while in Dr. K. Venugopalan's study there is $64 \%$ great improvement. This highlights the ability of Kudumbashree to empower women. In the study conducted by Santhosh Prabhu(11) in Kasargod, $40 \%$ had accessibility to loan while in this study $59 \%$ had easy access to loan. This shows that Kudumbashree in our area was more beneficial to women.

\section{CONCLUSION}

The study has provided an insight on women empowerment acquired by Kudumbashree members after joining Kudumbashree. Economic development is the basis for other development. Economic development of women leads to a better living status. The participation of women in social programmes, public meetings, and in banking and money transactions improved to a great extent. Kudumbashree has enhanced entrepreneurship and leadership and the capacity of women to work and earn together. Empowering women and improving their economic and social status are essential 
for realising the full potential of economic and political development of the entire society.

\section{REFERENCES}

[1] Kalyani K, Seena PC. Socio-economic changes of women through Kudumbashree a study from Puthenvelikkara (Gp) of Kerala state. International research journal of social science 2012;1(2):1-7.

[2] Taramol KG. Eradication of poverty and women empowerment-a study of Kudumbashree project in Ernakulam district of Kerala, India. International review of research in emerging markets and the global economy (IREM) an online research journal 2014;1(4):236-41.

[3] Kudumbashree wikipedia 2016. Available from: http://en. wikipedia. org/wiki/Kudumbashree.

[4] Gurumoorthy R. Self-help groups empower rural women, Kurukshetra 2000;48(5):22.

[5] Puhazhendhi V, Satyasai KJS. Economic and social empowerment of rural poor through self-help group. Indian Journal of Agricultural Economics 2001;56 (3): 450
[6] Jaya S. Self-Help groups in empowering women: a study of selected SHGs and NHGs in Kerala, KKRPLLD, centre for development studies, Trivandrum, Kerala, India, 1999.

[7] Raghavan VP. Micro-credit and empowerment: a study of Kudumbashree projects in Kerala, India. Journal of Rural Development, NIRD, Hyderabad 2009;28(4):478-9.

[8] Minimol MC, Makesh KG. Empowering rural women in Kerala: a study on the role of self-help groups (SHGs). International Journal of Sociology and Anthropology 2012;4(9):270-80.

[9] Beena CA, Sari TC. Socio-economic changes of women through Kudumbashree a study from Thrissur corporation of Kerala state, India, vistas 2014;3(1):30-6.

[10] Venugopalan K. Influence of Kudumbashree on women empowerment - a study. IQSR Journal of business and management studies (IOSR-JBM) 2014;16(10):35-44.

[11] Prabu SM. A research study on overall performance of Kudumbashree unit with reference to Kasargod district. Journal of humanities and social sciences 2015;20(10): 31-5. 